\title{
ANALISIS PENYIMPANGAN PENGGUNAAN LAHAN BERDASARKAN RENCANA TATA RUANG WILAYAH KABUPATEN SUMEDANG
}

\author{
Analysis of Land Use Deviation Based on Spatial Plan in Sumedang \\ Regency
}

Reny Khaerani ${ }^{1}$, Santun R.P Sitorus² ${ }^{2}$ Omo Rusdiana ${ }^{3}$

Diterima: 18 Oktober 2017 Disetujui: 27 November 2018

\begin{abstract}
Abstrak: Rencana tata ruang adalah hasil perencanaan tata ruang yang dilakukan melalui proses dan prosedur penyusunan serta penetapan berdasarkan ketentuan perundang-undangan yang berlaku. Fenomena yang sering terjadi adalah adanya penyimpangan penggunaan lahan eksisting dengan rencana tata ruang. Kabupaten Sumedang mengalami perkembangan yang cukup pesat, sehingga terjadi peningkatan aktivitas sumberdaya manusia yang berimplikasi pada meluasnya kebutuhan ruang dan akibatnya penyimpangan penggunaan lahan sangat rentan terjadi. Tujuan penelitian ini untuk mengetahui sejauh mana penyimpangan penggunaan lahan tersebut terjadi serta faktor-faktor apa saja yang mempengaruhinya. Analisis yang digunakan dalam penelitian ini menggunakan pendekatan SIG, Analisis Komponen Utama dan Analisis Regresi Berganda. Hasil analisis menunjukan bahwa terdapat 25 jenis penyimpangan penggunaan lahan dan yang paling dominan adalah penyimpangan menjadi sawah (18,364 ha), ladang (8,405 ha) dan lahan terbangun (7,741 ha). Sedangkan faktor-faktor yang mempengaruhi terjadinya penyimpangan penggunaan lahan adalah penduduk dan permukiman, ketersediaan lahan, infrastruktur dan aksesibilitas serta kondisi sosial ekonomi masyarakat.
\end{abstract}

Kata kunci: penyimpangan penggunaan lahan, rencana tata ruang wilayah, Analisis Komponen Utama

\begin{abstract}
Spatial plan is the result of spatial planning which is done through the process and procedure of arranging and determining based on the prevailing laws and regulations. The phenomenon that often happens is the deviation of existing land use with spatial plan. Sumedang Regency is experiencing a fairly rapid development, so there is an increase in human resource activity that implicate the widespread space needs and consequently deviation of land use is very vulnerable. The purpose of this study to determine the extent of deviation of land use occurs as well as what factors affect the occurence of irregular use of land. The analysis used in this study using GIS approach, Principal Component Analysis and Multiple Regression Analysis. The result of analysis shows that there are 25 types of deviation of existing land use and the most dominant is deviation into wetland (18,364 ha), dryland field (8,405 ha) and widened land (7,741 ha). While the factors that influence the occurence of deviation of land use are population and settlement, availability of land, infrastructure and accessibility, and sosioeconomic condition of society.
\end{abstract}

Keywords:deviation of land use, spatial plan, Principal Component Analysis

\footnotetext{
${ }^{1}$ Program Magister Ilmu Perencanaan Wilayah, Fakultas Pertanian, IPB

${ }^{2}$ Departemen Ilmu Tanah dan Sumberdaya Lahan, Fakultas Pertanian, IPB

${ }^{3}$ Departemen Silvikultur Kehutanan, Fakultas Kehutanan, IPB
} 


\section{PENDAHULUAN}

Kegiatan manusia tidak terlepas dari kebutuhan terhadap ruang yang merupakan tempat manusia tinggal dalam upaya untuk meningkatkan status dan kualitas hidupnya. Pertumbuhan penduduk dan perkembangan teknologi yang terjadi saat ini menimbulkan peningkatan kebutuhan akan ruang, dimana perubahan perilaku dan tuntutan aspirasi masyarakat menyebabkan perubahan pola dalam membentuk kebijaksanaan tata ruang. Ketersediaan lahan relatif terbatas sehingga tidak mustahil jika banyak terjadi konversi lahan dari kawasan budidaya pertanian ataupun kawasan lindung menjadi kawasan terbangun.

Penataan ruang pada dasarnya merupakan implementasi dari pembangunan daerah. Menurut UU Nomor 26 Tahun 2007 tentang Penataan Ruang, tata ruang merupakan wujud dari struktur ruang dan pola ruang, sedangkan penataan ruang adalah suatu sistem proses perencanaan tata ruang, pemanfaatan ruang, dan pengendalian pemanfaatan ruang. Rencana tata ruang adalah hasil perencanaan tata ruang yang dilakukan melalui proses dan prosedur penyusunan serta penetapan rencana tata ruang berdasarkan ketentuan perundang-undangan yang berlaku. Atas dasar penjelasan tersebut maka rencana tata ruang disusun melalui proses perencanaan yang disertai kesadaran penuh akan aspek pemanfaatan ruang dalam operasionalnya dan aspek pengendalian dalam implementasi dan evaluasinya (Prayitno, 2016). Penyusunan rencana tata ruang perlu memperhatikan fungsi yang harus diemban oleh masing-masing ruang/kawasan. Bila suatu penataan ruang tidak didasari pertimbangan rasional sesuai dengan potensi wilayah tersebut, maka dapat terjadi inefisiensi ruang atau penurunan kualitas ruang. Hal ini dapat berdampak pada rusaknya lingkungan dan beresiko mengalami bencana yang dapat muncul secara tak terduga.

Fenomena yang terjadi saat ini adalah adanya ketidaksesuaian atau penyimpangan penggunaan lahan eksisting dengan rencana tata ruang. Dengan terbatasnya ketersediaan lahan maka akan terjadi berbagai permasalahan dalam pengalokasian ruang karena faktor kepentingan. Penyimpangan struktur dan pemanfaatan ruang dalam RTRW umumnya terjadi karena tekanan tingginya pertumbuhan penduduk, terutama akibat arus urbanisasi. Perkembangan spasial yang tidak terkendali tersebut bukan berarti suatu wilayah tidak mempunyai konsep/perencanaan tata ruang/tata spasialnya. Formulasi tata spasial dan aplikasinya kalah cepat berpacu dengan proses perubahan spasial yang ada di lapangan, karena permasalahan yang berkaitan dengan aplikasi peraturan tidak dilaksanakan secara konsisten dan konsekuen (Yunus, 2005).

Kabupaten Sumedang dalam melakukan penataan ruang telah menyusun RTRW 2011-2031 yang ditetapkan dengan Peraturan Daerah Nomor 2 Tahun 2012. Kabupaten Sumedang mengalami perkembangan yang cukup pesat karena berada pada jalur lalu lintas Bandung dan Cirebon, diikuti pertumbuhan jumlah penduduk pada tahun 2007 sebesar 1,112,433 jiwa, mengalami kenaikan $1.68 \%$ pada tahun 2014 menjadi 1,131,516 jiwa (BPS, 2008; BPS, 2015). Melihat kondisi diatas, terjadi peningkatan aktivitas sumberdaya manusia dalam menggunakan sumberdaya alam yang berimplikasi pada meluasnya kebutuhan ruang sehingga penyimpangan penggunaan lahan sangat rentan terjadi. Menurut Nugroho dan Dahuri (2004), pertumbuhan ekonomi dan penduduk yang memusat di wilayah perkotaan menuntut ruang yang lebih luas ke arah luar kota untuk berbagai aktivitas ekonomi dan permukiman.

Berdasarkan hal tersebut, perlu dilakukan analisis penyimpangan penggunaan lahan berdasarkan RTRW Kabupaten Sumedang untuk mengetahui sejauh mana penyimpangan penggunaan lahan tersebut terjadi serta faktor-faktor apa saja yang mempengaruhi terjadinya penyimpangan penggunaan lahan di Kabupaten Sumedang. 


\section{METODE PENELITIAN}

Penelitian ini dilaksanakan di Kabupaten Sumedang Provinsi Jawa Barat. Secara geografis luas wilayah Kabupaten Sumedang yaitu 155,872 ha yang terdiri dari 26 kecamatan (BPS, 2015). Kegiatan penelitian dilaksanakan pada bulan November 2016 sampai Juli 2017. Data yang digunakan dalam penelitian ini berupa data sekunder dan data primer. Data sekunder dikumpulkan dari berbagai instansi sesuai dengan substansi yang akan dikaji, yaitu dari Bappeda Kabupaten Sumedang, Kementerian Lingkungan Hidup dan Kehutanan serta Badan Pusat Statistik Kabupaten Sumedang. Data primer diperoleh dari hasil pengecekan lapang jenis penggunaan lahan, kuesioner dan hasil wawancara. Alat dan bahan yang digunakan dalam penelitian ini yaitu seperangkat komputer/laptop, software ArcGis, Microsoft Office 2010, Excell Stat dan GPS.

\section{Analisis Penggunaan Lahan Eksisting Tahun 2017}

Analisis ini bertujuan untuk mengetahui penggunaan lahan eksisting saat ini yaitu tahun 2017. Data yang digunakan adalah Peta Penutupan Lahan Tahun 2015. Hasil klasifikasi pada peta penutupan lahan diuji kebenarannya dengan melakukan pengecekan ke lapangan secara langsung untuk memperbaiki hasil klasifikasi. Jenis penggunaan lahan pada penelitian ini terdiri atas 8 jenis yaitu hutan, kebun campuran, ladang, lahan terbangun, lahan terbuka, sawah, semak belukar dan tubuh air. Hasil dari analisis ini adalah peta penggunaan lahan eksisting tahun 2017.

\section{Analisis Penyimpangan Penggunaan Lahan}

Tujuan analisis ini adalah untuk mengetahui penyimpangan penggunaan lahan (ruang) eksisting terhadap RTRW. Analisis dilakukan dengan membandingkan peta RTRW dan peta penggunaan lahan eksisting dengan cara menumpangtindihkan (overlay) kedua peta tersebut. Hasil dari analisis ini adalah lokasi penyimpangan penggunaan lahan eksisting terhadap RTRW.

\section{Analisis Faktor-Faktor yang Mempengaruhi Terjadinya Penyimpangan Penggunaan Lahan}

Untuk mengetahui faktor-faktor yang mempengaruhi terjadinya penyimpangan penggunaan lahan digunakan Analisis Komponen Utama atau Principal Component Analysis (PCA). Data yang digunakan dalam penelitian ini adalah data dari Potensi Desa (Podes) tahun 2014 Kabupaten Sumedang. Analisis Komponen Utama merupakan metode statistik multivarian yang bertujuan untuk memperkecil dimensi peubah asal sehingga diperoleh peubah baru (komponen utama) yang tidak saling berkorelasi tetapi menyimpan sebagian besar informasi yang terkandung dalam peubah asal (Adiningsih et al., 2003).

Selanjutnya dilakukan analisis regresi untuk mengetahui keeratan hubungan antara faktor-faktor penduga penyimpangan dengan luas penyimpangan RTRW. Analisis yang memiliki variabel bebas lebih dari satu disebut analisis regresi linier berganda yang digunakan untuk mengetahui ada tidaknya pengaruh signifikan dua atau lebih variabel bebas terhadap variabel terikat (Amrin, 2016). Adapun yang menjadi variabel terikat (y) adalah luas penyimpangan RTRW yang diperoleh dari data atribut Peta Lokasi Penyimpangan Penggunaan Lahan, sedangkan variabel bebas (x) merupakan komponen utama yang terbentuk dari hasil analisis faktor.

Pengecekan lapangan dilakukan pada lokasi-lokasi yang terjadi penyimpangan serta dilakukan pula wawancara dan pengisian kuesioner. Teknik pengambilan sampel yang digunakan adalah Purposive Sampling yaitu sampel dipilih secara cermat dan selektif yang dianggap dapat mewakili lokasi penyimpangan dalam memberikan informasi yang representatif tentang masyarakat setempat dan kondisi lapangan. 


\section{HASIL DAN PEMBAHASAN}

Peta Penggunaan Lahan tahun 2017 di Kabupaten Sumedang dihasilkan dari Peta Penutupan Lahan tahun 2015 serta hasil pengecekan lapang. Verifikasi lapang dilakukan untuk memperbaiki klasifikasi penggunaan lahan pada atribut Peta Penutupan Lahan. Pengecekan lapang dilakukan di beberapa titik pengamatan. Beberapa Kecamatan yang dipilih antara lain Kecamatan Buahdua, Cimalaka, Darmaraja, Jatigede, Jatinangor, Pamulihan, Paseh, Sumedang Utara, Tanjungsari dan Ujungjaya. Pengambilan titik-titik sampel pada saat pengecekan lapang dilakukan secara representatif untuk mewakili berbagai jenis penggunaan lahan yang tersebar di beberapa kecamatan terpilih. Jenis dan luas penggunaan lahan di Kabupaten Sumedang tahun 2017 disajikan pada Tabel 1.

Tabel 1. Luas Penggunaan Lahan Tahun 2017 di Kabupaten Sumedang

\begin{tabular}{rlrr}
\hline No & Jenis Penggunaan Lahan & \multicolumn{2}{c}{ Tahun 2017 } \\
\cline { 3 - 4 } & & Luas (ha) & $\%$ \\
\hline 1 & Hutan & 58,917 & 37.80 \\
2 & Kebun Campuran & 17,289 & 11.09 \\
3 & Ladang & 32,826 & 21.06 \\
4 & Lahan Terbangun & 10,828 & 6.95 \\
5 & Lahan Terbuka & 448 & 0.29 \\
6 & Sawah & 34,629 & 22.22 \\
7 & Semak Belukar & 127 & 0.08 \\
8 & Tubuh Air & 808 & 0.52 \\
\hline
\end{tabular}

Sumber : Data Diolah (2017)

Penggunaan lahan di Kabupaten Sumedang terdiri atas delapan jenis yaitu hutan, kebun campuran, ladang, lahan terbangun, lahan terbuka, sawah, semak belukar dan tubuh air. Berdasarkan Tabel 1 dapat dilihat persentase komposisi penggunaan lahan di Kabupaten Sumedang pada tahun 2017. Jenis penggunaan lahan tahun 2017 yang memiliki persentase diatas $10 \%$ mendominasi yaitu hutan seluas 58,917 ha (37.80 \%), sawah 34,629 ha $(22.22 \%)$, ladang 32,826 ha $(21.06 \%)$, dan kebun campuran seluas 17,289 ha $(11.09 \%)$. Berdasarkan Gambar 1, secara agregat hutan terluas berada di Kecamatan Conggeang seluas 6,166 ha, kemudian sawah terluas di Kecamatan Ujungjaya 3,965 ha lalu kebun campuran terluas berada di Kecamatan Surian sebesar 3,131 ha dan ladang sebesar 4,165 ha terletak di Kecamatan Wado.

Penyimpangan penggunaan lahan merupakan bentuk perubahan/konversi penggunaan lahan yang tidak sejalan dengan RTRW. Peta Lokasi Penyimpangan diperoleh dengan melakukan overlay antara Peta Penggunaan Lahan Eksisting Tahun 2017 dengan peta RTRW tahun 2011-2031. Berdasarkan Gambar 2, penyimpangan penggunaan lahan di Kabupaten Sumedang tersebar di seluruh wilayah kecamatan. Kecamatan Buahdua dan Kecamatan Ujungjaya paling banyak terjadi penyimpangan yaitu masing-masing sebesar 2,476 ha dan 2,695 ha. Sedangkan luas penyimpangan terkecil terjadi di Kecamatan Jatinangor sebesar 413 ha.

Alokasi ruang untuk pertanian lahan basah adalah seluas 17,317 ha dan lahan kering seluas 23,114 ha. Berdasarkan Gambar 3, penyimpangan tertinggi terjadi pada pertanian lahan kering menjadi sawah seluas 6,266 ha dan pertanian lahan basah menjadi ladang seluas 5,240 ha. Selain itu, penyimpangan yang juga banyak terjadi pada alokasi ruang keduanya adalah berubahnya menjadi lahan terbangun dengan total luas penyimpangan mencapai 4,757 ha. Sektor pertanian merupakan penyumbang terbesar dalam PDRB Kabupaten Sumedang dalam kurun waktu lima tahun terakhir baik pertanian lahan basah 
maupun lahan kering. Faktor yang mempengaruhi terjadinya konversi lahan pertanian adalah produktivitas lahan, daerah rawan bencana dan yang paling signifikan mempengaruhi adalah pertumbuhan ekonomi (Hidayat, 2008; Firmansyah dan Purwadio, 2013).

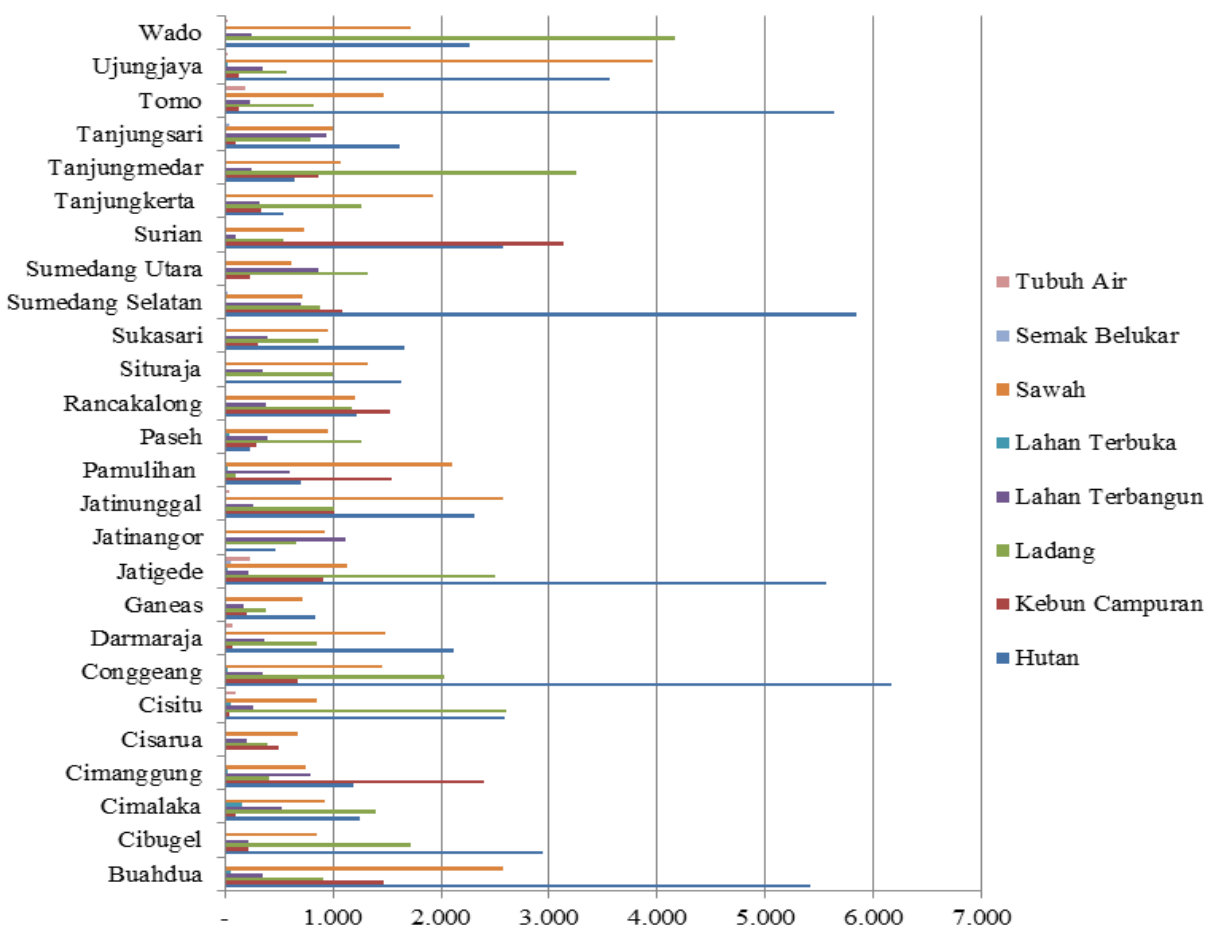

Gambar 1 Penggunaan Lahan Tahun 2017 per Kecamatan di Kabupaten Sumedang

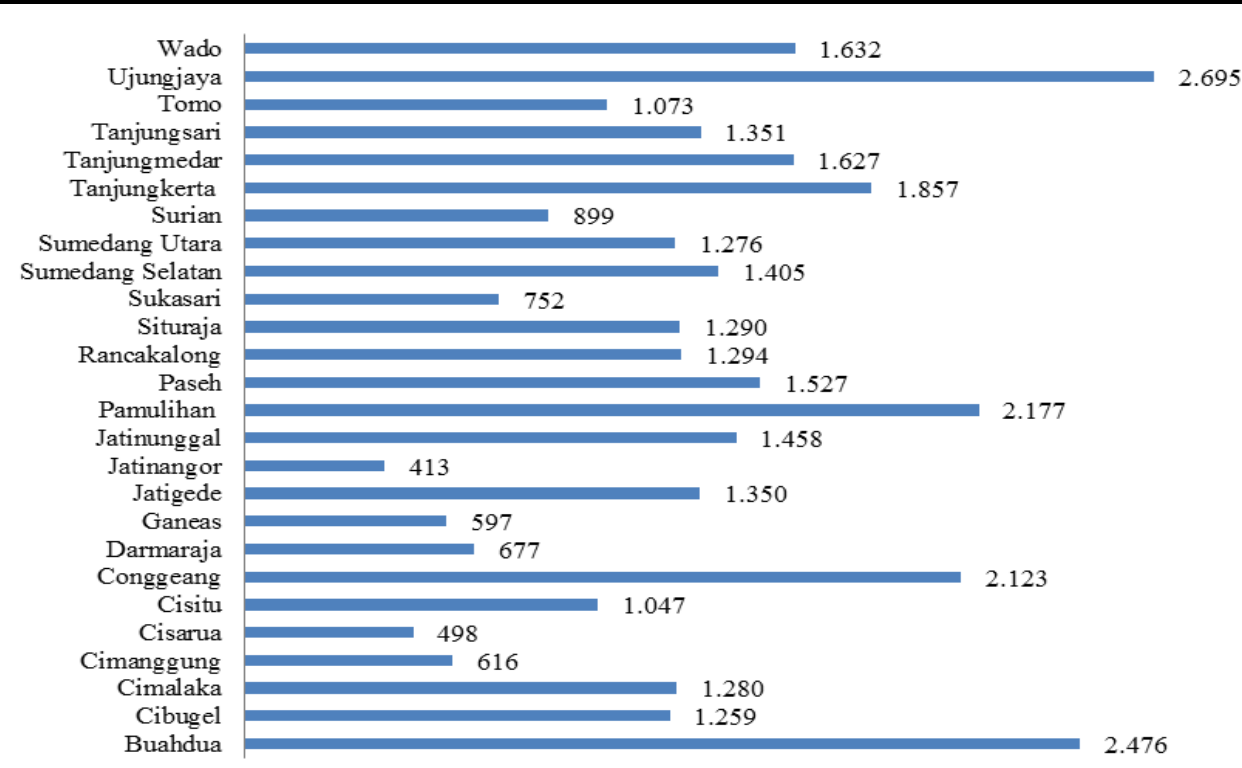


Kawasan hutan adalah wilayah tertentu yang ditunjuk atau ditetapkan oleh pemerintah untuk dipertahankan keberadaannya sebagai hutan tetap. Kawasan hutan baik Hutan Produksi (HP) maupun Hutan Produksi Terbatas (HPT) di Pulau Jawa dikelola oleh Perum Perhutani. Berdasarkan Gambar 3 dapat dilihat penyimpangan penggunaan lahan pada kawasan hutan yang paling banyak terjadi adalah HP menjadi sawah seluas 2,798 ha dan HPT menjadi ladang seluas 1,242 ha. Antoko et al (2008) berpendapat bahwa terjadinya alih fungsi lahan hutan menjadi penggunaan lahan lainnya seperti pemukiman, perkebunan, sawah, dan tambak disebabkan oleh tingginya permintaan terhadap lahan akibat kebutuhan sosial ekonomi.

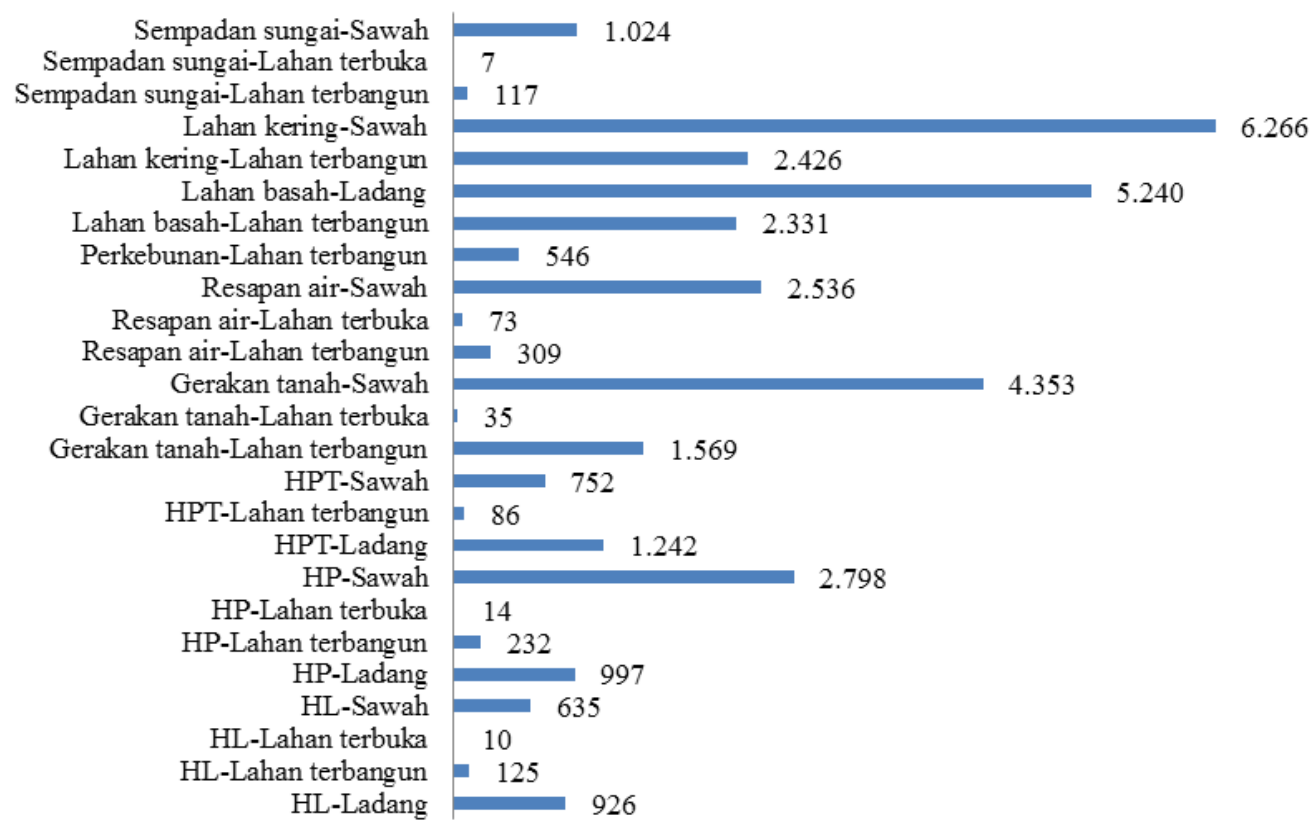

\section{Gambar 3 Jenis dan Luas Penyimpangan Penggunaan Lahan dalam hektar}

Jenis penyimpangan selanjutnya yang paling banyak terjadi pada kawasan rawan bencana gerakan tanah adalah perubahan menjadi sawah seluas 4,353 ha dan lahan terbangun seluas 1,569 ha. Kawasan ini merupakan kawasan yang berdasarkan kondisi geologi dan geografi dinyatakan rawan longsor atau kawasan yang mengalami kejadian longsor dengan frekuensi cukup tinggi, tersebar di seluruh wilayah kecamatan. Kabupaten Sumedang bagian selatan memiliki kerentanan gerakan tanah sedang hingga sangat tinggi seperti di Kecamatan Sumedang Selatan, Cimanggung, Rancakalong, Situraja, dan Darmaraja. Salah satu faktor yang mempengaruhi tingkat kerentanan adalah tata guna lahan (Sugianti et al., 2014).

Kawasan resapan air adalah kawasan yang mempunyai kemampuan tinggi untuk meresapkan air hujan, sehingga merupakan tempat pengisian air bumi (akuifer) yang berguna sebagai sumber air. Kawasan ini tersebar diseluruh kecamatan. Penyimpangan yang paling banyak terjadi pada kawasan ini adalah perubahan menjadi sawah yaitu seluas 2,536 ha. Daerah sempadan sungai juga mengalami penyimpangan penggunaan lahan. Sempadan sungai adalah kawasan sepanjang kanan kiri sungai, yang mempunyai manfaat penting untuk mempertahankan kelestarian fungsi sungai. Jenis penyimpangan pada daerah sempadan sungai tertinggi adalah perubahan menjadi sawah yaitu seluas 1,024 ha. 
Menurut Rahadi (2006) dan Putra et al (2015), kondisi fisik sempadan sungai sangat dipengaruhi oleh keadaan sosial ekonimi dan aktivitas masyarakat yang tinggal disekitarnya.

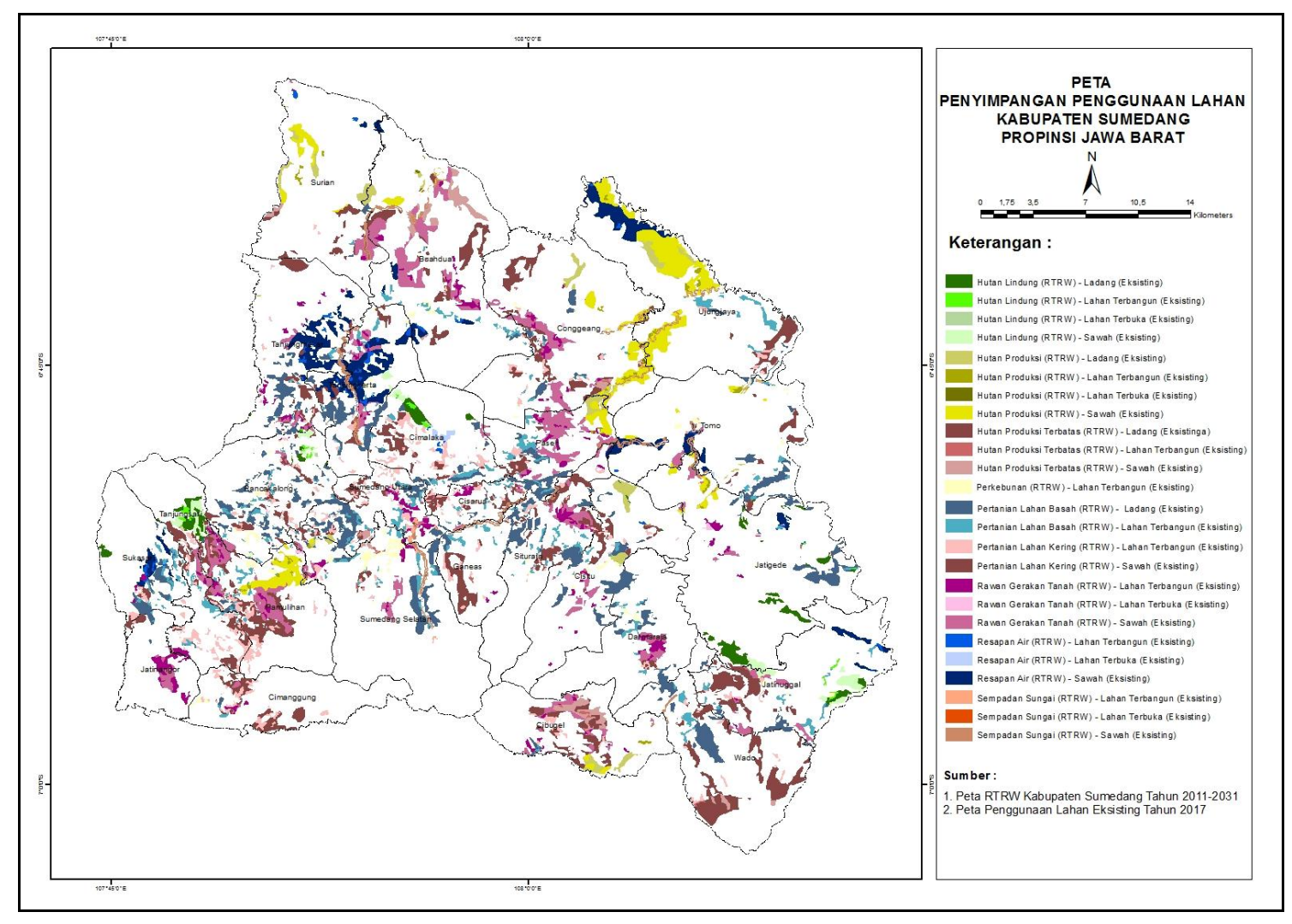

Gambar 4 Peta Penyimpangan Penggunaan Lahan Kabupaten Sumedang

Tabel 2 Variabel Penduga yang Mempengaruhi Penyimpangan Penggunaan Lahan di Kabupaten Sumedang

\begin{tabular}{cl}
\hline Kode & \\
\hline x1 & Luas wilayah \\
x2 & Jumlah penduduk \\
x3 & Kepadatan penduduk \\
x4 & Jumlah rumah permukiman kumuh \\
x5 & Jumlah keluarga permukiman kumuh \\
x6 & Jumlah keluarga di sekitar bantaran sungai \\
x7 & Jumlah bangunan rumah di sekitar bantaran sungai \\
x8 & Luas lahan sawah \\
x9 & Luas sawah dengan pengairan yang diusahakan \\
x10 & Luas lahan pertanian bukan sawah \\
x11 & Luas lahan non pertanian \\
x12 & Jarak ke Ibukota Kabupaten \\
x13 & Jumlah fasilitas pendidikan \\
x14 & Jumlah fasilitas kesehatan \\
x15 & Jarak ke pusat pelayanan pendidikan \\
x16 & Jarak ke pusat pelayanan kesehatan \\
\hline
\end{tabular}


Sumber : Data Diolah (2017)

Analisis yang dilakukan selanjutnya adalah Principal Component Analysis (PCA) untuk mengetahui faktor-faktor yang diduga mempengaruhi penyimpangan penggunaan lahan. Data yang digunakan adalah data Potensi Desa Tahun 2014. Berdasarkan beberapa hasil penelitian terdahulu seperti yang dilakukan oleh Marisan (2006), Restina (2009) dan Fahmi et al. (2016), data Podes yang terpilih sebagai variabel penduga yang mempengaruhi penyimpangan penggunaan lahan ditunjukan pada Tabel 2 .

Tabel 3 Faktor yang Terbentuk Berdasarkan Hasil Analisis Komponen Utama

\begin{tabular}{lrrrr}
\hline & \multicolumn{4}{c}{ Komponen Utama } \\
\cline { 2 - 5 } \multicolumn{1}{c}{ Variabel } & \multicolumn{1}{c}{1} & \multicolumn{1}{c}{2} & \multicolumn{1}{c}{3} & \multicolumn{1}{c}{4} \\
\hline Luas wilayah & -0.4507 & 0.0820 & 0.1215 & -0.1081 \\
Jumlah penduduk & $\mathbf{0 . 8 9 9 4}$ & 0.1284 & 0.1640 & -0.2358 \\
Kepadatan penduduk & $\mathbf{0 . 8 6 1 9}$ & -0.2951 & 0.1501 & $-0,1945$ \\
Jumlah rumah permukiman kumuh & 0.4545 & 0.4617 & -0.1744 & $\mathbf{0 . 6 1 7 4}$ \\
Jumlah keluarga permukiman kumuh & 0.4532 & 0.4452 & -0.1655 & $\mathbf{0 . 6 1 0 3}$ \\
Jumlah keluarga di sekitar bantaran sungai & 0.4421 & $\mathbf{0 . 7 2 3 3}$ & -0.1650 & -0.1581 \\
Jumlah bangunan rumah di sekitar bantaran sungai & 0.4157 & $\mathbf{0 . 7 0 2 6}$ & -0.2210 & -0.1450 \\
Luas lahan sawah & -0.4511 & 0.4297 & 0.4610 & -0.1711 \\
Luas sawah dengan pengairan yang diusahakan & -0.4538 & 0.3888 & 0.0716 & -0.0758 \\
Luas lahan pertanian bukan sawah & -0.3173 & 0.3638 & -0.2197 & -0.2978 \\
Luas lahan non pertanian & -0.0476 & 0.8604 & 0.1259 & 0.1277 \\
Jarak ke Ibukota Kabupaten & -0.4684 & 0.2630 & -0.0893 & 0.1828 \\
Jumlah fasilitas pendidikan & $\mathbf{0 . 8 2 3 6}$ & 0.0913 & 0.2194 & -0.3103 \\
Jumlah fasilitas kesehatan & 0.0592 & -0.1669 & $\mathbf{0 . 7 4 4 1}$ & 0.4456 \\
Jarak ke pusat pelayanan pendidikan & $\mathbf{0 . 7 7 5 1}$ & 0.2425 & 0.4322 & -0.2863 \\
Jarak ke pusat pelayanan kesehatan & 0.0508 & -0.2288 & $\mathbf{0 . 7 5 4 9}$ & 0.2342 \\
\hline
\end{tabular}

Sumber : Data Diolah (2017)

Berdasarkan Tabel 3 dapat dijelaskan bahwa, komponen utama 1 merupakan faktor yang paling berpengaruh terhadap terjadinya penyimpangan penggunaan lahan, yaitu jumlah penduduk, kepadatan penduduk, jumlah fasilitas pendidikan dan jarak ke pusat pelayanan pendidikan. Hal ini menunjukan hubungan bahwa semakin meningkatnya jumlah penduduk maka kepadatan penduduk semakin tinggi, sehingga akan berpengaruh terhadap jumlah fasilitas pendidikan dan jarak ke pusat layanan pendidikan. Aksesibilitas atau kemudahan untuk mencapai pusat layanan pendidikan akan meningkatkan kesejahteraan masyarakat yang pada akhirnya akan meningkatkan kebutuhan lahan.

Komponen utama 2 faktor yang berpengaruh adalah jumlah keluarga di sekitar bantaran sungai, jumlah bangunan rumah di sekitar bantaran sungai dan luas lahan non pertanian. Hal ini menunjukan hubungan antara luas lahan non pertanian dengan banyaknya jumlah keluarga dan bangunan di sekitar bantaran sungai. Lahan disekitar bantaran sungai dapat dimanfaatkan sebagai lahan pertanian (ladang). Penggunaan lahan disekitar bantaran menjadi lahan terbangun merupakan pelanggaran garis sempadan sungai yang selanjutnya diduga berpengaruh terhadap penyimpangan dan dapat menyebabkan menurunnya luas lahan pertanian atau dengan kata lain luas lahan non pertanian meningkat.

Komponen utama 3 faktor yang berpengaruh adalah jumlah fasilitas kesehatan dan jarak ke pusat pelayanan kesehatan. Hal ini menunjukan hubungan fasilitas infrastruktur 
kesehatan, dimana semakin banyak jumlah fasilitas kesehatan menyebabkan jarak ke pusat pelayanan kesehatan semakin dekat dan akan diikuti dengan peningkatan kebutuhan lahan.

Komponen utama 4 faktor yang berpengaruh adalah jumlah rumah permukiman kumuh dan jumlah keluarga permukiman kumuh. Hal ini menunjukan semakin banyak jumlah keluarga yang tinggal di permukiman kumuh juga akan meningkatkan jumlah bangunan di permukiman kumuh yang pada akhirnya akan meningkatkan intensitas terhadap penggunaan lahan.

Tahap selanjutnya yang dilakukan adalah analisis regresi untuk mengetahui seberapa kuat faktor yang terbentuk dari komponen utama mempengaruhi penyimpangan penggunaan lahan. Berdasarkan hasil analisis regresi, model yang dibangun cukup baik untuk menjelaskan faktor-faktor yang mempengaruhi kesesuaian penggunaan lahan, hal ini ditunjukan dengan nilai $\mathrm{R}^{2}$ (0.4752) yang bermakna bahwa variabel bebas mampu menerangkan $47.52 \%$ variabel terikat sedangkan sisanya dijelaskan oleh variabel lain yang tidak dimasukan dalam model penelitian ini. Faktor-faktor yang mempengaruhi penyimpangan penggunaan lahan yang menjadi variabel bebas dalam model regresi ini menunjukan bahwa keempatnya memiliki pengaruh yang nyata terhadap penyimpangan penggunaan lahan. Hal ini ditunjukan dengan hasil nilai signifikansi uji yang memiliki nilai lebih kecil dari nilai signifikansi penelitian yang ditetapkan (0.05). Hasil analisis regresi sebagaimana dapat dilihat pada Tabel 4.

Tabel 4 Hasil Analisis Regresi Berganda

\begin{tabular}{lrrrr}
\hline \multicolumn{1}{c}{ Source } & \multicolumn{1}{c}{ Value } & Standard error & \multicolumn{1}{c}{$\mathrm{t}$} & $\operatorname{Pr}>|\mathrm{t}|$ \\
\hline Intercept & 1332,6877 & 91,5901 & 14,5506 & $<0,0001$ \\
Komponen Utama 1 & 112,1965 & 40,2747 & 2,7858 & 0,0111 \\
Komponen Utama 2 & 98,5581 & 48,0743 & 2,0501 & 0,0350 \\
Komponen Utama 3 & 54,6389 & 58,4404 & 0,9350 & 0,0436 \\
Komponen Utama 4 & 185,2097 & 74,5367 & 2,4848 & 0,0215 \\
$\mathrm{R}^{2}=0,4752$ & & & & \\
\hline
\end{tabular}

Sumber : Data Diolah (2017)

Penyimpangan penggunaan lahan tidak lepas dari faktor perilaku serta latar belakang masyarakat yang menempatinya. Selain menggunakan analisis PCA dan regresi linier berganda, untuk mengetahui faktor-faktor yang mempengaruhi terjadinya penyimpangan penggunaan lahan dilakukan wawancara kepada masyarakat di lokasi terjadinya penyimpangan. Wawancara dan kuesioner dilakukan secara purposive sampling. Hasil wawancara dapat diketahui keadaan sosial ekonomi masyarakat di lapangan yaitu tingkat pendidikan masyarakat masih rendah, pekerjaan masyarakat sebagian besar sebagai petani, buruh atau pengangguran, kepemilikan tanah sebagian besar adalah lahan sendiri atau warisan, pengetahuan masyarakat mengenai rencana tata ruang masih rendah, kurang sosialisasi dari pemerintah pada masyarakat mengenai RTRW.

Tingkat pendidikan sangat berpengaruh terhadap perilaku masyarakat. Pendidikan yang rendah membuat orang cenderung untuk melanggar aturan, sedangkan bagi masyarakat yang berpendidikan lebih mengetahui resiko yang ada apabila terjadi penyimpangan penggunaan lahan terhadapa RTRW. Dengan kata lain dapat dikatakan seseorang yang memiliki pendidikan tinggi memiliki pengetahuan untuk tidak menggunakan lahan yang tidak sah. Pengetahuan dalam menentukan keputusan untuk bertindak atau memilih suatu resiko didasarkan pada pandangan rational choice. Sastraprateja dalam Restina (2009) mengemukakan bahwa pengetahuan menghasilkan nilai untuk menentukan atau memilih. 
Pekerjaan sangat terkait dengan pendapatan. Hal ini berpengaruh terhadap keputusan untuk menempati lahan. Masyarakat yang berpenghasilan rendah cenderung untuk mengabaikan faktor legal dalam memiliki tanah karena keterbatasan biaya, sehingga mempunyai keterbatasan dalam melakukan investasi pembelian lahan yang dapat dijadikan tempat tinggal. Status kepemilikan lahan di lokasi penyimpangan sebagian besar lahan sendiri dan warisan. Status kepemilikan ini dapat mendorong terjadinya penyimpangan penggunaan lahan karena dapat dengan mudah berpindah tangan/kepemilikan. Hal ini dipengaruhi akan kebutuhan yang mendesak dan nilai ekonomis lahan cukup tinggi, sehingga sulit untuk mencegah terjadinya konversi lahan.

Pengetahuan masyarakat yang rendah mengenai rencana tata ruang dapat menyebabkan orang tidak menyadari bahwa telah menempati tempat yang salah atau tidak sesuai. Selain itu kurang sosialisasi dari pemerintah pada masyarakat mengenai RTRW menyebabkan masyarakat tidak tahu rencana apa yang akan dibangun di lokasi tempat tinggalnya.

\section{KESIMPULAN}

Berdasarkan hasil analisis penyimpangan penggunaan lahan di Kabupaten Sumedang, terdapat 25 jenis penyimpangan penggunaan lahan eksisting terhadap pola ruang RTRW Kabupaten Sumedang dan yang paling dominan adalah penyimpangan menjadi sawah (pertanian lahan basah) seluas 18,364 ha, ladang (pertanian lahan kering) seluas 8,405 ha dan lahan terbangun (permukiman) seluas 7,741 ha.

Adapun Faktor-faktor yang mempengaruhi terjadinya penyimpangan penggunaan lahan dari pola ruang RTRW di Kabupaten Sumedang adalah (1) faktor penduduk dan permukiman, (2) ketersediaan lahan, (3) infrastruktur dan aksesibilitas serta (4) kondisi sosial ekonomi masyarakat seperti pendidikan, pekerjaan, pendapatan, kepemilikan lahan serta tingkat pengetahuan masyarakat tentang rencana tata ruang wilayah.

Pemerintah daerah disarankan lebih berperan dalam mengendalikan penggunaan lahan yang tidak sejalan dengan RTRW melalui pemberian ijin mendirikan bangunan yang diperketat sesuai dengan RTRW dan memberlakukan sistem insentif dan disinsentif sesuai dengan Undang-Undang No.26 Tahun 2007. Selain itu perlu dikaji ulang alokasi ruang untuk pertanian lahan basah dan lahan kering mengingat penggunaan lahan eksisting untuk keduanya melebihi dari alokasi ruang yang direncanakan pada RTRW 2011-2031.

\section{UCAPAN TERIMA KASIH}

Ucapan terimakasih kami sampaikan kepada Pusat Pendidikan dan Pelatihan Kementerian Lingkungan Hidup dan Kehutanan yang telah memberikan beasiswa pendidikan pascasarjana.

\section{DAFTAR PUSTAKA}

Adiningsih ES, Mahmud, Effendi I. 2004. Aplikasi Analisis Komponen Utama dalam Pemodelan Penduga Lengas Tanah dengan Data Satelit Multispektral. Jurnal Matematika dan Sains. 9(1): 215-222.

Amrin. 2016. Data Mining dengan Regresi Linier Berganda untuk Peramalan Tingkat Inflasi. Jurnal Techno Nusa Mandiri. 13(1): 74-79.

Antoko BS, Sanudin, Sukmana A. 2008. Perubahan Fungsi Hutan di Kabupaten Asahan, Sumatera Utara. Info Hutan. V(4): 307-316.

[BPS] Badan Pusat Statistik Kabupaten Sumedang. 2008. Kabupaten Sumedang Dalam Angka Tahun 2008. Sumedang (ID): Badan Pusat Statistik Kabupaten Sumedang.

[BPS] Badan Pusat Statistik Kabupaten Sumedang. 2015. Kabupaten Sumedang Dalam Angka Tahun 2015. Sumedang (ID): Badan Pusat Statistik Kabupaten Sumedang. 
Fahmi F, Sitorus SRP, Fauzi A. 2016. Evaluasi Pemanfaatan Penggunaan Lahan Berbasis Rencana Pola Ruang Kota Baubau Provinsi Sulawesi Tenggara. Junal Tata Loka. 18(1): 27-39.

Firmansyah F, Purwadio H. 2013. Arahan Pengendalian Konversi Lahan Pertanian ke Non-Pertanian di Kabupaten Gresik. Jurnal Teknik Pomits. 2(1). ISSN: 2337-3539.

Hidayat SI. 2008. Analisis Konversi Lahan Sawah di Propinsi Jawa Timur. Jurnal Sosial Ekonomi Pertanian. 2(3): 48-58.

Marisan M. 2006. Analisis Inkonsistensi Tata Ruang Dilihat dari Aspek Fisik Wilayah : Kasus Kabupaten dan Kota Bogor. [Tesis]. Bogor (ID): Institut Pertanian Bogor.

Nugroho I, Dahuri R. 2012. Pembangunan Wilayah Perspektif Ekonomi, Sosial dan Lingkungan. Jakarta (ID): LP3ES.

Prayitno S. 2016. Sinkronisasi Tata Ruang Wilayah dengan Program Pembangunan Kota Bogor. [Tesis]. Bogor (ID): Institut Pertanian Bogor.

Putra SE, Rohmat D, Jupri. 2015. Evaluasi Pemanfaatan Sempadan Sungai Indragiri di Kabupaten Indragiri Hilir Propinsi Riau. Antopolgi Geografi. 3(2): 1-16.

Rahadi B. 2006. Identifikasi Pemanfaatan Lahan dan Air di Sempadan Sungai Brantas. Jurnal Teknologi Pertanian. 7(3): 206-216.

Restina N. 2009. Evaluasi Penggunaan Lahan Eksisting dan Arahan Penyusunan Rencana Tata Ruang Kota Tasikmalaya Provinsi Jawa Barat. [Tesis]. Bogor (ID): Institut Pertanian Bogor.

Sekretariat Negara. UURI No. 26 Tahun 2007 tentang Penataan Ruang (2007).

Sugianti K, Mulyadi D, Sarah D. 2014. Pengklasan Tingkat Kerentanan Gerakan Tanah Daerah Sumedang Selatan Menggunakan Metode Storie. Riset Geologi dan Pertambangan. 24(2): 93-104.

Yunus HS. 2005. Manajemen Kota Perspektif Spasial. Yogyakarta (ID): Pustaka Pelajar. 